\title{
A Preliminary Investigation on the Presence of Calcifying Nanoparticles in the Breast Tumor
}

\author{
Pinar OZKAL-BAYDIN ${ }^{1}$, Sedef J. GOCMEN ${ }^{2}$, Esra ERDEMLI ${ }^{3}$, Ibrahim G. TUNC ${ }^{4}$, \\ Hasan B. SENER ${ }^{5}$, Berrak GUMUSKAYA ${ }^{5}$, Asuman SUNGUROGLU ${ }^{1}$ \\ ${ }^{1}$ Ankara University, Faculty of Medicine, Department of Medical Biology \\ ${ }^{2}$ Başkent University, Faculty of Medicine, Department of Medical Microbiology \\ ${ }^{3}$ Ankara University, Faculty of Medicine, Department of Histology \\ ${ }^{4}$ Dışkapı Yıldırım Beyazıt Training and Research Hospital, Department of General Surgery \\ ${ }^{5}$ Dışkapı Yıldırım Beyazıt Training and Research Hospital, Department of Pathology, Ankara / TURKEY
}

\begin{abstract}
Calcium phosphate is deposited in many diseases, but the molecular basis of mineralization remains largely unknown. Biomineralizied calcifications that are formed by calcium deposits are also detected in breast mammograms. Some of the detected microcalcifications are thought to be related with malignancy. Taken together, calcifying nanoparticles (CNP) may be thought as a source of malign calcifications in breast cancers. The aim of the study is to research the presence of CNP in breast tumor tissue. With this aim, the presence of CNP was investigated by culturing 16 patients' breast tumor tissue and from 2 pathologic tissues with transmission electron microscopy (TEM) and scanning electron microscopy (SEM). Their growth was monitored by optical density (OD) at a wavelength of $650 \mathrm{~nm}$. CNP couldn't be found in the analysed tissues. The presence of CNP in the breast tumor tissue was researched for the first time. We could not find CNP in the breast tumor tissue, but we think this research will open a new field of study for researchers.
\end{abstract}

Keywords: Breast tumor, Calcification, Calcifying nanoparticles, Scanning electron microscopy, Transmission electron microscopy

\section{ÖZET}

\section{Meme Tümöründe Kalsifiye Edici Nanopartiküllerin Varlığına Dair Bir Ön İnceleme}

Kalsiyum fosfat depolanması pek çok hastalıkta görülür, fakat mineralizasyonun moleküler nedeni büyük oranda bilinmemektedir. Kalsiyum depolanmasıyla oluşan biyomineral kalsifikasyonlar mamogramla saptanmaktadır. Saptanan mikrokalsifikasyonların bazılarının maligniteyle ilişkili olabileceği düşünülmektedir. Tüm bu bilgiler göz önüne alındığında, kalsifiye edici nanopartiküller (CNP) malign kalsifikasyonların nedeni olarak düşünülebilir. Bu çalışmanın amacı, meme tümör dokusunda CNP varlığını araştırmaktır. Bu amaçla, CNP varlığı 16 hastanın meme tümör dokusunun kültürü sonrası ve 2 patolojik dokunun geçirimli ve taramalı elektron mikroskopları (TEM ve SEM) ile incelenmesi ve 650 nm'de optik densitenin ölçülmesi ile araştııımıştır. Analiz edilen dokularda CNP saptanamamıştır. Bu çalışmayla, CNP varlığı ilk defa meme tümör dokusunda araştııımışıı. Meme tümör dokusunda CNP bulunamamakla birlikte bu çalışmanın araştırmacılara yeni araşıırma alanları açacağı düşünülmektedir.

Anahtar Kelimeler: Meme tümörü, Kalsifikasyon, Kalsifiye edici nanopartiküller, Taramalı elektron mikroskobu, Geçirmeli elektron mikroskobu 


\section{INTRODUCTION}

The formation of organized inorganic crystalline structures within macromolecular extracellular matrices is referred to as "biomineralization". Mammalian bone and dental enamel are examples of biomineralization. The formation mechanisms of mineralization remain speculative and largely unknown. ${ }^{1}$ Calcification of soft tissues, termed "pathologic calcification" is a common process in a wide variety of diseases ${ }^{2}$ like aortic valve stenosis, atherosclerosis and psammoma bodies in ovarian cancer. ${ }^{3-6}$ Breast calcifications are deposits of calcium that can be seen on breast mammograms. ${ }^{7}$ One of the most important roles of calcification detection in mammography is the identification of malignancy. The other important role is in the follow up of breast cancer patients having breast conservation therapy as calcifications have been detected in $29-80 \%$ of recurrences. Morover, there is an increased risk of malignancy associated with an increased number of calcifications. ${ }^{2}$ Calcifications associated with benign conditions are usually larger, fewer in number, widely dispersed, and round. ${ }^{7}$

There are two forms of microcalcification in breast disease: Type I and Type II. Type I is composed of calcium oxalate and these oxalate calcifications are generally associated with proliferating but noninvasive diseases of the breast. On the other hand, Type II consists predominantly of calcium phosphate. Calcium phosphate in the crystalline form of hydroxyapatite is usually correlated to invasive malign tumors. The mechanism that causes deposition of the bonespecific mineral hydroxyapatite has not yet been illuminated. ${ }^{7}$

Calcifying nanoparticles (CNP) (nanobacteria, nanons, nanobes, nanobacteria-like particles) were discovered as cell culture contaminants by Kajander et al in bovine and human blood in the last decade of 20th century. The name is derived from the very small size of these nanoparticles, which varies from 50 nanometers to 500 nanometers. The defining characteristics of CNP is their outer envelope composed of calcium phosphate that presents on transmission electron microscope images as an electron-dense shell surrounding a translucent central core. They produce carbonate apatite on their cell envelope from soluble calcium and phosphorus at physiologic concentrations and conditions. However, there is still a big debate about whether these self-mineralizing particles are bacteria or inorganic substances with the capacity for extensive crystallization..$^{8-10}$

Discovery of CNP initiated further studies and have now been implicated in a wide array of human diseases associated with calcifications like: kidney stone formation ${ }^{1}$, prostatitis ${ }^{11}$, psammoma bodies in ovarian cancer $^{6,12}$, Randall's plaque ${ }^{13}$, testicular microlithiasis $^{14}$, calcification in placenta ${ }^{15}$, calcific aortic valve stenosis $^{4,16}$, atherosclerotic plaques ${ }^{5}$, and dental pulp stones. ${ }^{17}$

Taken together, since microcalcifications are one of the most common abnormalities detected on screening mammography for breast cancer ${ }^{7}$ and CNP has been shown to contribute to different benign and malign calcifications ${ }^{11-16}$, CNP may also contribute to malign calcifications in breast cancer. Thus, in the light of these investigations and results, this study focuses on researching the presence of CNP in calcified breast tumor tissues for the first time.

\section{MATERIALS AND METHODS}

\section{Clinical sample collection}

All enrolled patients agreed to sign written consent forms and the study was approved by Kırıkkale University Ethics Board. Sixteen women, aged 43-74 (median 57), all having breast carcinoma (7; infiltrative ductal, 5 ; invazive ductal, 1 ; mucinose, 1 ; metaplastic, 1 ; mix type-infiltrative ductal+infiltrative lobuler-, and 1; inflamatuar carcinoma) were accepted for this study. In addition to 16 patients' tumor tissues, 2 paraffin embedded breast tumor tissues are included in this study.

\section{Cultivation of calcifying nanoparticles}

Before culturing tumor tissues, we prepared cultures with DMEM supplemented with $10 \%$ fetal bovine serum (FBS) (filtered through $0.22 \mu \mathrm{m}$ filters) to observe CNP under mammalian cell culture conditions $\left(37^{\circ} \mathrm{C}, 5 \% \mathrm{CO}_{2}, 95 \%\right.$ air). These were our positive control cultures. The incubation period was 6-8 weeks.

The breast tumor tissues were divided into two parts: one of which was kept at $4^{\circ} \mathrm{C}$ for direct analysis without culturing and the other part was crushed in a sterile glass petri by sterile surgical blades under laminair flow. It was demineralized by adding $1 \mathrm{M} \mathrm{HCl}$, which was subsequently neutralizied with $1 \mathrm{M} \mathrm{NaOH}$. The resultant was filtrated with a $0.22 \mu \mathrm{m}$ membrane filter and cultured in DMEM supplemented with 10\% 


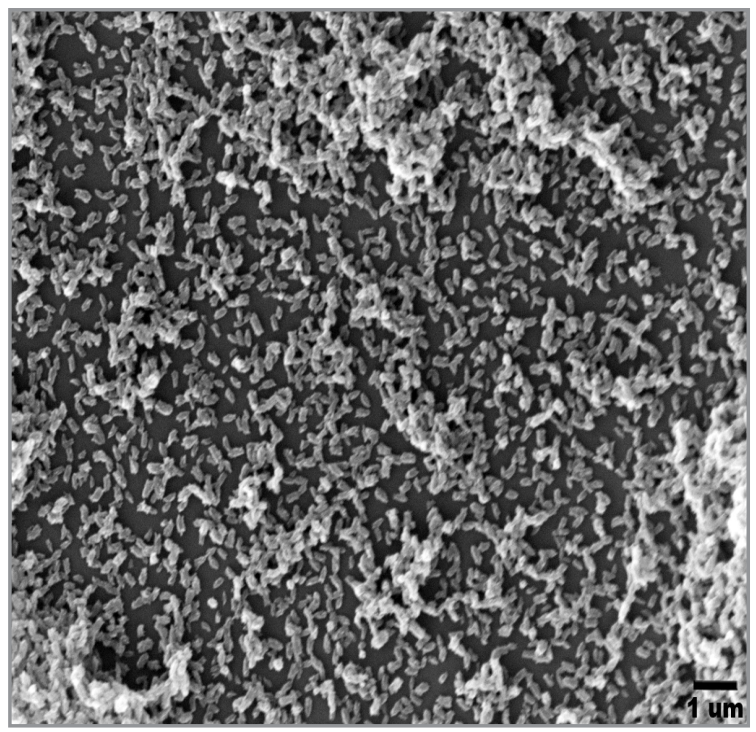

Figure 1. Scanning electron micrograph of calcifying nanoparticles.

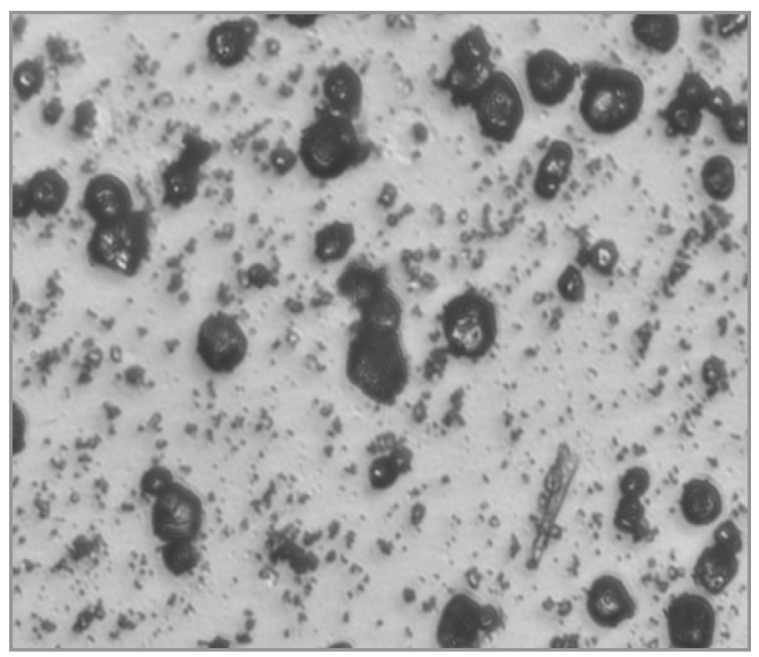

Figure 3. Transmission electron micgraph of calcifying nanoparticles (Original magnification is 129.300X)

gamma-irradiated $(\gamma)$ and $0.22 \mu \mathrm{m}$ membrane filtrated FBS at $37^{\circ} \mathrm{C}$, under $5 \% \mathrm{CO}_{2}$ atmosphere. ${ }^{16}$ Also, cultures without tumor tissue cultured under the same conditions were used as the negative controls. After 6-8 weeks of incubation, a culture scraping was executed in each flask, then centrifuged at $5000 \mathrm{x} \mathrm{g}$ for 45 minutes and pellets were obtained.

\section{Transmission electron microscopy (TEM)}

PBS washed pellets were fixed by immersion in 2.5\% gluteraldehyde in $0.1 \mathrm{M}$ phosphate buffer $(\mathrm{pH} 7.4)$ at room temperature for $3 \mathrm{hrs}$ and post - fixed in 1\%

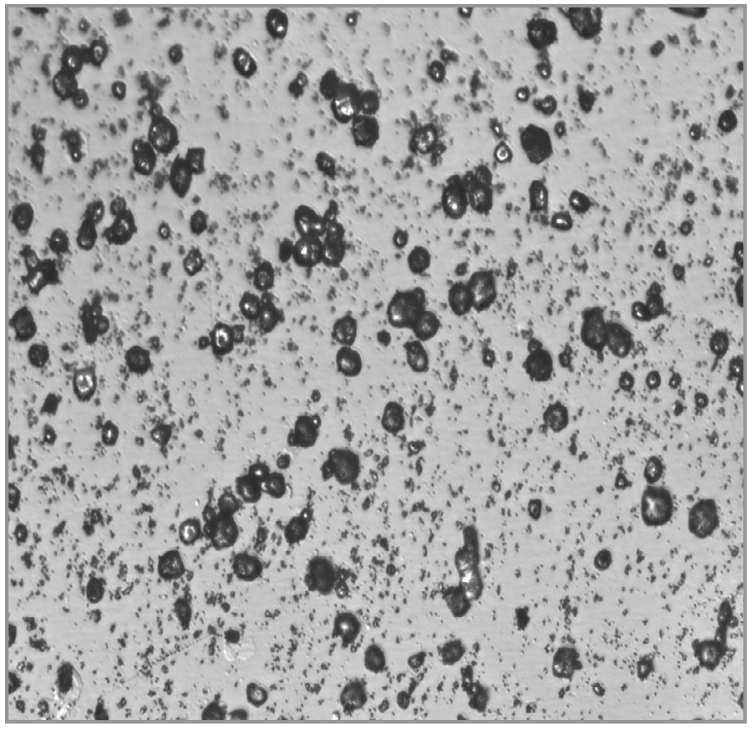

Figure 2. Transmission electron micgraph of calcifying nano particles (Original magnification is 100.000X).

phosphate buffered osmium tetroxide for $2 \mathrm{hrs}$. Samples were dehydrated by being passed through the graded ethanol series and embedded in Araldite CY212. Ultra thin sections were contrast stained with uranyl acetate and lead citrate and examined using the Leo 906 E (80 kV) (Oberkohen-Germany) transmission electron microscope. ${ }^{16,18}$

For preparing slides from pathological samples which were previously processed for standard histological examination, paraffin blocks were placed in 100\% xylene for 1-2 hrs until no evidence of paraffin remains then rehydration in ethanols was performed. After incubation in $1 \%$ osmium tetroxide for $1 \mathrm{hr}$, they were dehydrated and embeded in Araldite CY 212 as for routine TEM sample preparation. ${ }^{19}$

Also, breast tumor tissues of 16 patients that were kept at $4^{\circ} \mathrm{C}$, were screened by direct $\mathrm{x}$-ray to see calcificated areas. From 7 patients' calcificated breast tumor tissue areas, slides were prepared to be observed under TEM.

\section{Scanning electron microscopy (SEM)}

Only positive control cultures were screened by SEM. Pellets were washed with PBS then subcultured in serum-free RPMI-1640 on glass cover slips for 24 hrs. The glass cover slips were washed with PBS and fixed with $2 \%$ gluteraldehyde for $30 \mathrm{~min}$ at room temperature. Fixed samples were dehydrated with absolute alcohol; dried in a critical point dryer and layered with gold followed by examination in SEM. 


\section{Microbiologic tests}

To be sure about the non-existance of classical microbes in our CNP cultures, subcultures were performed on $200 \mu$ l pellets in a mycoplasma liquid medium, sheep-blood agar and eosin methylen blue (EMB) agar both in aerobic and anaerobic conditions. Morover, Gram and Giemsa stainings were done.

\section{Spectrophotometry}

Maximum absorbances of pellets were measured by spectrophotometer.

\section{RESULTS}

Calcifying nanoparticle culture results, imaging by TEM and SEM: After 8 weeks of culture, we could observe CNP like particules in our positive control cultures including DMEM supplemented with $10 \%$ FBS both with SEM and TEM. SEM of the positive control culture revealed coccobacillary particles with a diameter ranging between 100 and $200 \mathrm{~nm}$. The particles were prokaryotic in shape. (Figure 1). TEM also showed coccoid structures wrapped by a high electron-dense, thick outer shell (Figure 2 and 3 ). These morphologic and distinctive features are the same as those of CNP described in previous studies. ${ }^{1,18,20}$ But neither in the cultures with breast tumor tissues nor in our negative control cultures could we observe CNP.

TEM of pathologic tissue and calcified area results: From 2 pathologic breast tumor tissues and 7 patients' breast tumor tissues we tried to sign the calcified areas and tried to prepare slides for TEM only from these areas. CNP could not be imaged from these samples.

Microbiologic test results: A subculture of pellets on sheep blood agar, mycoplasma medium and EMB agar resulted without growing. Also, they couldn't be dyed by Gram and Giemsa.

Spectrophotometric results: Maximum absorbance of breast tumor tissue pellets was 550-560 nm.

\section{DISCUSSION}

CNP appear as self-propagating calcifying macromolecular complexes found in bovine and human blood and blood products. There are still discussions about their nature, as living or non-living and it is certain that the discussions will continue until their genome can be accurately sequenced. Whether they are phys- icochemical phenomenon or bacteria, they exist and cause diseases. ${ }^{10}$ The disease-causing mechanisms of CNP include the known effects of calcium on blood vessels, blood coagulation and thrombus formation; elevation of intracellular $\left[\mathrm{Ca}_{2}{ }^{+}\right]$levels and its consequences. They grow better in the presence of other bacteria and this could change the normal flora and promote bacterial infection. CNP adhere to foreign objects, such as implants, and could result in biofilm formation later attracting bacteria, leading to a chronic infectious problem that is often untreatable with antibiotics. ${ }^{21}$

Guneslioglu, et al. ${ }^{3}$ and Altundag, et al. ${ }^{7}$ hypohesized a possible association between breast implant capsule contracture, malignant calcifications in breast cancer and CNP. Breast calcification is an important feature in the radiological assessment of breast lesions. Good understanding of the morphologic features and the mechanism of calcifications is crucial for health care professionals involved in breast care. When we take different calcification mechanisms into consideration, pathologic calcification can be classified as dystropfic and metastatic calcification. Dystropfic calcification may be intra- or- extracellular. While the initiation in extracellular sites begins at membrane bound vesicles derived from degenerating cells; the initiation in intracellular sites begins in the mitochondria of the dead or dying cells. Calcifications detected in the breast is probably derived from dystropfic calcification, not from metastatic one. ${ }^{2}$ There are two types of calcification molecules in breast tissue. One is calcium oxalate, which is crystalline and is present mostly in benign lesions. The other is non crystalline, which is a form of calcium phosphate and is associated with malign lesions..$^{22}$ Osteopontin also appears to be a crucial mediator involved in the process of calcification. This mediator was found in the histiocytes around the lesional epithelial breast tissue, but at much lower level in tumor cells. In the scenario of high grade tumor, osteopontin expression may represent part of inflammatory response to cellular damage. In addition to construction mechanism of microcalcifications and the particles they include, the density, mass and number of calcifications are very important in the prognosis of breast lesions. ${ }^{2}$ For these reasons, in this study we planned to investigate the presence of CNP in calcified breast tumor tissues. Ciftcioglu, et al. ${ }^{23}$ found that CNP were best detected after cultivation. So, we prepared three types of 
culture: One type was a positive control including DMEM with $10 \%$ FBS. This cultures' aim was to culture and image CNP. These bacteria like particles can not grow and reproduce under common conditions for microbial culture, but need media for mammalian cell culture such as Roswell Park Memorial Institute (RPMI) 1640 medium or Dulbecco modified eagle medium to grow (DMEM). ${ }^{10,11}$ FBS was used as a supplement and source of CNP. The second type was the negative control cultures including DMEM with $10 \% \gamma$ FBS. If FBS was added into the culture medium directly, it gives false positive results. Fortunately, the destructive effects of $\gamma$ ray irradiation on FBS can effectively eliminate powerful inhibitors of apatite crystal formation. ${ }^{24}$ So, we used $\gamma$ FBS to avoid false positive results and did not expecting to observe CNP in these cultures as in the previous studies. ${ }^{1,24,25}$ The last culture was the same with our negative cultures, but we added our demineralized, neutralized and 0.22 $\mu \mathrm{m}$ pore filtered breast tumor tissues to these cultures. Morover, FBS and $\gamma$ FBS were both filtered before cultivation to prevent contamination by other bacteria or fungi. It has also been shown that, nucleation capacity could be lost after 0.1 or $0.05 \mu \mathrm{m}$ membrane filtration. ${ }^{25}$ After 8 weeks of culture, we were able to manage to image CNP only in our positive controls, but not in the cultures of breast tumor tissues. Also, spectrophotometric measurements would indicate the presence of CNP if we measured OD650, but our results were OD550-OD560. This result made us think about the amount of calcification of our tissues. To be sure about imaging calcified breast tumor areas, we screened 16 patients breast tumor tissue that we were keeping at $4^{\circ} \mathrm{C}$ by direct $\mathrm{x}$-ray. For seven of the 16 tissues, we were able to check off calcified areas and tried to prepare slides for TEM from these calcified areas. Morover, we again prepared 2 slides for TEM from paraffin embedded calcified brest tumor tissues. But with the same result as our previous one, we could not observe CNP by TEM in these samples.

Several methods are being used to detect CNP, like bacterioscopic, bacteriological, serological, genomic or proteomic methods, although some of these are still questinable. ${ }^{10}$ However, TEM is still a powerful tool for detecting and studying CNP. ${ }^{9}$ If we are able to see CNP by TEM in tumor tissue samples, we could try PCR-based detection of the universal $16 \mathrm{~S}$ rRNA gene $^{9,26}$ or immunefluorescence staining with $8 \mathrm{D} 10 .{ }^{27}$ Kajander and Ciftcioglu have discovered CNP in hu- man and cow blood first1; then they developed their experiments by researching other mammalian cell cultures. They have shown the adherence of CNP to 3T6 and other fibroblasts. CNP were bound as clusters on the cell surfaces. Adherence took place on cellular extensions and to the perinuclear area of the cells. They thought CNP are internalized either by receptor-mediated endocytosis or by a closely related pathway. ${ }^{1,20}$ This important experiment have shown that, CNP have the ability to invade mammalian cells. Many mammalian malign cells have receptors for CNP adherence ${ }^{1}$ that could introduce CNP into the tumor with subsequent calcification. ${ }^{20}$ Guo et al 9 speculated that the CNP detected in their placental tissue calcification was a novel type of nanoscale bacteria distinct from the nanobacteria isolated from kidney stones and human blood, as reported elsewhere. They assumed that different nanobacteria may induce calcification by receptors in different human tissues, like nanobacteria receptor mediated tumor tissue calcification. There might exist a special cell adhesion molecule in the outer membrane of the CNP to invade a cell. In the light of this research, the receptor-mediated endocytosis pathway mechanism used by CNP may not be suitable for breast cells at all.

In our study, the reason we could not observe CNP in the calcified breast tumor tissue may be a result of insufficient calcified areas such that the amounts of calcified areas were too small to isolate or they were lost in some steps. It is also said that calcification depends on the amount of calcifying nanoparticles present. ${ }^{9}$ Moreover, it might be possible for us to see CNP in the calcified breast tumor tissue, if we could have a chance to culture more breast tumor tissues.

In this study, the presence of CNP in the breast tumor tissue was researched for the first time. Isolating and culturing CNP from breast tumor tissue has not been reported before. We think that this investigation will open a new area for researchers. Therefore, we wonder if new culture parameters, tools and techniques can be used and developed in this new research area.

\section{Acknowledgment}

This work was supported by Ankara University Research Foundation (Project No: 2007-08-09-052 HPD). The authors would like to acknowledge the contribution of Prof. Alp Can from Ankara University, Faculty of Medicine, Department of Histology for SEM image. 


\section{REFERENCES}

1. Kajander EO, Ciftcioglu N. Nanobacteria: An alternative mechanism for pathogenic intra-and extracellular calcification and stone formation. Proc Natl Acad Sci USA 95: 8274-8279, 1998.

2. Tse GM, Tan PH, Cheung HS, et al. Intermediate to highly suspicious calcification in breast lesions: a radio-pathologic correlation. Breast Cancer Res Treat 110: 1-7, 2008.

3. Gundeslioglu O, Altundag O, Altundag K. Nanobacteria and breast implant capsule contracture and calcification: a hypothesis. Aesth Plast Surg 29: 582, 2005.

4. Jelic TM, Chang $\mathrm{H}$, Roque R, et al. Nanobacteria-associated calcific aortic valve stenosis. J Heart Valve Dis 16: 101-105, 2007.

5. Puskas LG, Tislavics L, Razga ZS, Torday LL, Krenacs T, Papp JGy. Detection of nanobacteria-like particles in human atherosclerotic plaques. Acta Biol Hungarica 56: 233-245, 2005.

6. Sedivy R, Battistutti WB. Nanobacteria promote crystallization of psammoma bodies in ovarian cancer. APMIS 111: 951954, 2003.

7. Altundag K, Altundag O, Akyurek S, Atik MA. Possible association between nanobacteria and malign microcalcifications in breast cancer. Breast J 12: 287, 2006.

8. Jelic TM, Roque $R$, Yasar $U$, et al. Calcifying nanoparticles associated encrusted urinary bladder cystitis. Int J Nanomed 3: 385-390, 2008.

9. Guo Y, Zhang D, Lu H, et al. Association between calcifying nanoparticles and placental calcification. Int $\mathrm{J}$ Nanomed 7: 1679-1686, 2012.

10. Kutikhin AG, Brusina EB, Yuzhalin AE. The role of calcifying nanoparticles in biology and medicine. Int J Nanomed 7: 339350, 2012.

11. Zhou Z, Hong L, Shen $X$, et al. Detection of nanobacteria infection in type III prostatitis. Urology 71: 1091-1095, 2008.

12. Hudelist G, Singer CF, Kubista E, et al. Presence of nanobacteria in psammoma bodies of ovarian cancer. Evidence for pathogenic role in intrtumoral biomineralization. Histopathology 45: 633-637, 2004.

13. Ciftcioglu N, Vejdani $K$, Lee $O$, et al. Association between Randall's plaque and calcifying nanoparticles. Int J Nanomed 3: 105-115, 2008.

14. Zhang Q, Lu G, Shen X, et al. Nanobacteria may be linked to testicular microlithiasis in infertility. J Androl 31: 121-125, 2010.

15. Lu H, Guo Y, Liu S, Zhang D. Nanobacteria may be linked to calcification in placenta. Ultrastruct Pathol 36: 160-165, 2012.

16. Bratos-Perez MA, Sanchez PL, deCruz SG, et al. Association between self-replicating calcifying nanoparticles and aortic stenosis. A possible link to valve calcification. Eur Heart J 29: 371-376, 2008.
17. Yang F, Zeng J, Zhang W, Sun X, Ling J. Evaluation of the interaction between calcifying nanoparticles and human dental pulp cells: a preliminary investigation. IInt J Nanomed 6: 13-18, 2011.

18. Khullar M, Sharma SK, Singh SK, et al. Morphological and immunological characteristics of nanobacteria from renal stones of a North Indian population. Urol Res 32: 130-35, 2004.

19. Dykstra MJ. A Manual of Applied Techniques for Biological Electron Microscopy. New York and London, Plenum Press, 1993: $75-77$.

20. Ciftcioglu N, Kajender EO. Interaction of nanobacteria with cultured mammalian cells. Pathophysiology 4: 259-270, 1998.

21. Kajander EO. Nanobacteria-propagating calcifying nanoparticles. Lett Appl Microbiol 42: 549-552, 2006.

22. Gonzalez JE, Caldwell RG, Valaitis J. Calcium oxalate crstals in the breast. Pathology and significance. Am J Surg Pathol 15: 586-591, 1991.

23. Ciftcioglu N, Bjorklund M, Kuorikoski K, et al. Nanobacteria. An infectious cause for kidney stone formation. Kidney Int 56: 1893-1898, 1999.

24. Wen Y, Li Y, Yang Z, et al. Detection of nanobacteria in serum, bile and gallbladder mucosa of patients with cholecystolithiasis. Chin Med J 118: 421-424, 2005.

25. Cisar JO, Xu D, Thompson J, Swaim W, Hu L, Kopecko DJ. An alternative interpretation of nanobacteria-induced biomineralization. PNAS 97: 11511-11515, 2000.

26. Raoult D, Drancourt M, Azza S, et al. Nanobacteria are mineralo fetuin complexes. Plos Pathogens 4: e41, 2008.

27. Hu R, Zhao $Y$, Sun $Y$, et al. Detection of nanobacteria-like material from calcified cardiac valves with rheumatic heart disease. Cardiovasc Pathol 19: 286-292, 2010.

\section{Correspondence}

Dr. Pınar ÖZKAL BAYDIN

Ankara Üniversitesi

Kök Hücre Enstitüsü

Ceyhun Atıf Kansu Cad. No: 169

Cevizlidere, Balgat

ANKARA / TURKEY

Tel: (+90.312) 5957116

e-mail: ozkal@medicine.ankara.edu.tr 